\title{
Optimization of hydrolysis of sardine (Sardina pilchardus) heads with Protamex: enhancement of lipid and phospholipid extraction
}

\author{
Justine Dumay ${ }^{1}$, Marion Allery ${ }^{1}$, Claire Donnay-Moreno ${ }^{1}$, Gilles Barnathan ${ }^{2}$, Pascal Jaouen ${ }^{3}$, Marie \\ Elise Carbonneau ${ }^{4}$, Jean Pascal Bergé ${ }^{1, *}$
}

\author{
${ }^{1}$ IFREMER, Nantes Atlantique Universités, F 44311 Nantes, France \\ ${ }^{2}$ MMS, EA 2160, Nantes Atlantique Universités, France \\ ${ }^{3}$ GEPEA, UMR-CNRS 6144, CRTT, Nantes Atlantique Universités, Saint-Nazaire, France \\ ${ }^{4}$ CTPA, MAPAQ, Québec, Canada \\ *: Corresponding author : Jean Pascal Bergé, email address : jpberge@ifremer.fr
}

\begin{abstract}
:
BACKGROUND: Fish by-products are not considered as valuable raw materials even if they usually contain valuable components such as lipids. Fish lipids are well known for their nutritional potential and health effects but their extraction remains problematic due to the use of organic solvents. Enzymatic hydrolysis such as the proteolysis of tissues can lead to lipid extraction.

RESULTS: Hydrolysis of sardine heads by Protamex was studied (temperature, hydrolysis time and enzyme-substrate ratio) using response surface methodology in order to obtain the highest release of lipids and particularly phospholipids. No relation between the degree of hydrolysis and lipid recovery were depicted; however, optimum conditions for both the release of lipids and phospholipids were found to be similar $\left(29 \mathrm{~min}, 31{ }^{\circ} \mathrm{C}\right.$ with $2.6 \mathrm{~g} \mathrm{~kg}-1$ enzyme). Under these hydrolysis conditions, rich lipid and phospholipid fractions (oily and aqueous fractions) can be recovered when time, temperature and enzyme consumption are minimized. Analytical data have revealed that they contain high-quality lipids, especially 3 fatty acid.
\end{abstract}

CONCLUSION: This study demonstrated that proteolysis can be used for high lipid recovery from little-exploited biomass like fish heads without requiring solvent or thermal treatment. Resulting phospholipids, fatty acids and peptides could be utilized for nutritional or feed purposes.

Keywords: phospholipids - fatty acids $\cdot$ by-product - sardine - proteolysis - response surface methodology 


\section{Introduction}

Worldwide, total fisheries production was about 140 million tons. ${ }^{1}$ In France, sardine (Sardina pilchardus) represents the first landed fish: about 22000 tons in $2004^{2}$ and it is mainly consumed canned. Such processing leads to high volume of by-products (about $30 \%$ of the whole fish), ${ }^{3}$ corresponding to an annual French production of more than 6000 tons. Fish processing by-products are commonly recognized as low value resources with negligible market value. Nowadays, they are mainly used for meal, oil or pet food mince production. Hence, there is a great opportunity here to increase the added value of these by-products.

Biochemical compositions of fish have been widely described and have shown great nutritional values and their by-products possess quite similar composition. ${ }^{4,5}$ Among the different nutritional compounds lipids, and particularly $\omega 3$ and phospholipids, from fatty fish are of interest. Indeed, in addition to their nutritional value, marine phospholipids have also exhibited antitumoral activities ${ }^{6}$ while synthetic phospholipids were realised for antiviral uses. ${ }^{7,8}$ Fatty acids also offer potential values. A large number of articles have described benefits of $\omega 3$ fatty acids: on blood circulation, thrombose, hypertriglycemia, ${ }^{9}$ on blood pressure regulation, ${ }^{10}$ against schizophrenia, ${ }^{11}$ stress and depression, ${ }^{12}$ on foetal development ${ }^{13}$ and the most widely discussed is the benefit against cardiovascular disease. ${ }^{14-17}$ Marine organisms seem to be a wide source of such fatty acids ${ }^{18}$ and marine by-products as well. ${ }^{19-21}$ Thus, the improvement on lipid recovery from fishery discards offers a large opportunity to reduce waste and increase profit from a highly valuable sub-product.

Hydrolysis processes have been developed to convert under-utilized fish and fish byproducts into a marketable and acceptable form, which can be widely used in food rather than as animal feed or fertilizer. Enzymatic tissue disruption may be an efficient alternative technique for releasing lipids. Previous studies on fish and fish by-products have shown that, when compared to classical organic extraction, lipid extraction is enhanced by a pre-hydrolysis step using wide-spectrum proteases ${ }^{22}$ and a part of the oil could be obtained after hydrolysis and centrifugation. ${ }^{23}$ A recent study conducted on sardine viscera has shown that hydrolysis with proteases allows and improves lipid and phospholipid release as compared with common method ${ }^{24}$ avoiding the use of drastic conditions (chemicals and heat).

Response surface methodology (RSM) is a useful technique for the investigation of complex processes such as enzymatic hydrolysis. Indeed, some papers have reported the optimisation of processing conditions, like $\mathrm{pH}$, temperature, enzyme concentration but they are essentially based on protein recovery ${ }^{25}$ or peptide biological activities. ${ }^{26}$

The purpose of this study is to develop efficient conditions for hydrolysis regarding the hydrolysis of sardine heads with Protamex. Hydrolysis time, temperature and enzyme concentration have been studied according to the experimental design procedure in order to remove the highest quantities of lipid and phospholipid from the by-product.

\section{Experimental}

All analyses have been performed in triplicates.

Materials 
Sardines (Sardina pilchardus) were provided from Pêcheries Océanes (Nantes, France) and were caught in the Atlantic North-East in April and June 2004. Fish were stored under ice less than $24 \mathrm{~h}$ and then filleted. Heads were collected and stored under vacuum at $-80^{\circ} \mathrm{C}$. Due to high variation in chemical composition of fish according to season, sex and length, ${ }^{27,28}$ samples coming from April and June were mixed together and homogenized with a blender (Waring Commercial, USA) for $1 \mathrm{~min}$. Samples were then stored at $-80^{\circ} \mathrm{C}$.

Enzyme used for hydrolysis was kindly provided by Novozymes AS (Denmark). Protamex is a Bacillus protease complex (EC numbers: 3.4.21.62 and 3.4.24.28). Protamex is developed for the hydrolysis of food proteins and fulfils the purity demands for food-grade enzymes, set by the joint FAO/WHO Expert Committee on Food Additives (JEFTA) and the Food Chemicals Codex (FCC). ${ }^{29}$ Optimal conditions for Protamex were determined in a previous study. ${ }^{3}$ Its deactivation temperature is reported by manufacturer to be $85^{\circ} \mathrm{C}$ for $10 \mathrm{~min}$.

Hydrolysis

The hydrolysis experiments were carried out using the pHstat method (TIM 854, Radiometer analytical, SAS, France) in a $250 \mathrm{~mL}$ glass reactor under controlled conditions ( $\mathrm{pH}$, temperature and stirring speed). Mixed by-products were homogenized with water (ratio 1/1, w/v). Enzyme was added to the mixture and the system was continuously stirred at $700 \mathrm{rpm}$ during hydrolysis. $\mathrm{pH}$ was maintained at the desired value $(\mathrm{pH}$ 8) by addition of $\mathrm{NaOH} 2 \mathrm{M}$. Therefore, the degree of hydrolysis $(\mathrm{DH})$ could be obtained following the formula:

$$
D H=\frac{V \cdot N \cdot 100}{\alpha \cdot m p \cdot h_{\text {tot }}}
$$

Where $\mathrm{V}$ : volume of sodium hydroxide consumed during hydrolysis in $\mathrm{mL}$

$\mathrm{N}$ : normality of sodium hydroxide

$\alpha$ : dissociation factor for $\alpha-\mathrm{NH}_{2}$ groups $=0.88$ at $50^{\circ} \mathrm{C}^{30}$

$\mathrm{mp}$ : mass of protein in $\mathrm{g}$ in the fresh matter introduced in the system (protein content was determined according to Crooke et al. ${ }^{31}$

$\mathrm{h}_{\text {tot }}$ : total number of peptide bounds in the protein $=8,6$ eq.g. $\mathrm{kg}^{-1}$ protein in fish samples After hydrolysis, the temperature was increased to $85^{\circ} \mathrm{C}$ for $10 \mathrm{~min}$ to inactivate the enzyme. The hydrolysate was then centrifuged at $20,000 \mathrm{~g}$ for $30 \mathrm{~min}$ at $4^{\circ} \mathrm{C}$. After centrifugation, the tubes were put upright in a freezer $\left(-20^{\circ} \mathrm{C}\right)$ and all fractions: sludges (or insoluble phases), oily phase and aqueous (or soluble) phase were separated by cutting the frozen content of the tubes. Each fraction was then freeze-dried and stored at $-20^{\circ} \mathrm{C}$ until analysis.

Dry matter content

Dry matter content was estimated gravimetrically after freeze-drying.

Ash content

Ash content was determined by heating samples at $600^{\circ} \mathrm{C}$ overnight.

Lipid extraction 
Lipid extraction was carried out according to the method described by Folch et al. ${ }^{32}$ About $1 \mathrm{~g}$ (exactly measured) of dry sample was homogenized in $4 \mathrm{~mL}$ distilled water. Methanol (Technical grade, Carlo Erba, France) was added to the mixture (ratio mixture/methanol: 3/20, w/v). Samples were then stirred for 30 min before adding chloroform (Technical grade, Carlo Erba, France) (ratio mixture/chloroform: 3/40, w/v). The system was stirred for 30 min before filtration and addition of 0.2 volume of water with $0.9 \% \mathrm{NaCl}$. After 15 hours decantation at $+4^{\circ} \mathrm{C}$ in separating funnel and in darkness, lipids were recovered in the organic phase. Lipid extracts were dried under vacuum in a rotary evaporator (temperature $<35^{\circ} \mathrm{C}$ ). Lipids were weighted and results expressed as $\mathrm{g}$ of lipid per $\mathrm{g}$ of dry matter. Lipids extracts were kept in $10 \mathrm{~mL}$ chloroform and stored at $-80^{\circ} \mathrm{C}$ until analysis.

\section{Phospholipid content of total lipid extracts}

Phospholipid content was evaluated by the colorimetric method of Stewart ${ }^{33}$ based on the formation of a complex between phospholipids and ammonium ferrothiocyanate. Ammonium ferrothiocyanate consisted of ferric chloride $\left(27 \mathrm{~g} \cdot \mathrm{L}^{-1}\right)$ and ammonium thiocyanate $\left(30 \mathrm{~g}^{-1} \mathrm{~L}^{-1}\right)$ in distilled water. One milliliter of this reagent was added to $2 \mathrm{~mL}$ of lipid extract in chloroform $(0.25 \mathrm{mg} / \mathrm{mL})$. The mixture was homogenized and centrifuged for $10 \mathrm{~min}$ at $750 \mathrm{~g}$. The absorbance of the lower phase was read at $488 \mathrm{~nm}$ against the blank. A standard curve was plotted with standard phosphatidylcholine in chloroform (5 to $50 \mu \mathrm{g} / \mathrm{mL}$ ) and results were expressed as g phosphatidylcholine equivalent / $g$ of dry matter.

\section{Lipid class distribution}

Lipid class was analysed twice, by TLC-FID to obtain a precise but destructive distribution and by solid phase extraction to recover neutral lipids and phospholipids.

The TLC-FID technique was realized according to an adaptation of the methods described by Parrish (1987) and Ackman et al. (1990) with a latroscan MK-6 (Shell, USA). ${ }^{34,35}$

The solid phase extraction and separation of lipid classes was performed using open glass column (internal diameter: 8-10 mm, length: $20 \mathrm{~cm}$ ) containing glass wool and silica gel (ratio silica gel/ oily sample: $30 / 1, \mathrm{w} / \mathrm{w}$ ). Chloroform (1 $\mathrm{mL} / \mathrm{mg}$ of oil sample), acetone/methanol $(9 / 1, \mathrm{v} / \mathrm{v} ; 1.5 \mathrm{~mL} / \mathrm{mg}$ of oil sample) then methanol $(1 \mathrm{~mL} / \mathrm{mg}$ of oil sample) were used to recover respectively neutral lipids, glycolipids and phospholipids. Each fraction was then stored at $-80^{\circ} \mathrm{C}$ until analysis.

\section{Fatty acid analysis}

Aliquot of lipid was evaporated under nitrogen and transmethylated by contact with methanol/sulphuric acid (98:2, V/V) in excess at $50^{\circ} \mathrm{C}$ overnight. After cooling, $2 \mathrm{~mL}$ of hexane and $1 \mathrm{~mL}$ of water were added and vortexed. The upper organic phase containing fatty acid methyl esters (FAMEs) was collected and assayed by GC using a Perkin Elmer Autosystem equipped with a FID detector. Separation was done using helium as carrier gas on a fused silica column (BPX-70, $60 \mathrm{~m}$ long, $0.25 \mathrm{~mm}$ i.d, $0.25 \mu \mathrm{m}$ film thickness, SGE) programmed from $55^{\circ} \mathrm{C}$ (for $2 \mathrm{~min}$ ) to $150^{\circ} \mathrm{C}$ at $20^{\circ} \mathrm{C} / \mathrm{min}$ then to $230^{\circ} \mathrm{C}$ at $1.5^{\circ} \mathrm{C} / \mathrm{min}$. Sample was injected with a programmable split/splitless inlet and large volume injection system (PSS) using the following temperature program: $55^{\circ} \mathrm{C}$ (for $2 \mathrm{~min}$ ) to $350^{\circ} \mathrm{C}$ at $200^{\circ} \mathrm{C} / \mathrm{min}$. FAMEs were identified by comparison of their equivalent 
chain length with those of authentic standards. Quantification was done using margaric acid (17:0) as internal standard.

\section{Protein content}

Crude protein content $(\mathrm{N} \times 6.25)$ was estimated in the heads and determined colorimetrically after Kjeldahl digestion using a method described by Crooke et al. ${ }^{31}$

Experimental design and evaluation

Response surface methodology (RSM) was used to investigate the influence of the hydrolysis variables: temperature, hydrolysis time and enzyme-substrate (E/S) ratio (g. $\mathrm{kg}^{-1}$ of raw heads) on the digestion of sardine heads and to optimize the influence of these three variables. In a $2^{3}$ Central Composite Design (CDD), the starting temperature, hydrolysis time and E/S ratio were varied systematically at high and low levels (Tables

Table 1). Two parallel center groups with medium levels of all the three factors studied were used to check the linear relationship between high and low levels of the variables tested. The measured variable responses were degree of hydrolysis (DH), lipid and phospholipid release. A total of 16 experiments were performed. The order of the experiments has been fully randomized. Analytical determinations were performed in triplicate. The mathematical analysis of data was conducted by the software Statgraphics plus v.5 experimental design. The accuracy of the model was further tested by conducting hydrolysis experiments.

\section{Results}

The proximate chemical composition of sardine heads was: $749 \pm 1$ g. $\mathrm{kg}^{-1}$ moisture; $64 \pm$ $0 \mathrm{~g} . \mathrm{kg}^{-1}$ ash; $58 \pm 2 \mathrm{~g} \cdot \mathrm{kg}^{-1}$ lipids and $137 \pm 5 \mathrm{~g} \cdot \mathrm{kg}^{-1}$ proteins.

Experimental design

Responses ( $\mathrm{DH}$, lipids and phospholipids) obtained for each experiment are reported in Table 2. Experiment 1 gave highest $\mathrm{DH}, 28 \%$, corresponding to a long hydrolysis (22h), a low temperature $\left(36^{\circ} \mathrm{C}\right)$ and a high enzyme concentration $\left(2.3 \mathrm{~g} \cdot \mathrm{kg}^{-1}\right)$. At the other extreme, the lowest $\mathrm{DH}(7 \%)$ was obtained conducting the experiment 11 with a short hydrolysis time $(6 \mathrm{~h})$, a low temperature $\left(36^{\circ} \mathrm{C}\right)$ and low enzyme concentration $\left(0.7 \mathrm{~g} \cdot \mathrm{kg}^{-}\right.$ $\left.{ }^{1}\right)$.

Regarding lipids and phospholipids, two responses have been examined: the total lipids for the evaluation of the total lipid quantity in the matrix, and the lipids released, corresponding to the part recovered into the liquid fractions (oily and soluble fractions). The $9^{\text {th }}$ experiment resulted in the highest lipid quantity with a short hydrolysis time (6h), a low temperature $\left(36^{\circ} \mathrm{C}\right)$ and a high enzyme concentration $\left(2.3 \mathrm{~g} . \mathrm{kg}^{-1}\right)$. Under such conditions, $0.29 \mathrm{~g}$ of lipids per $\mathrm{g}$ of dry matter was extracted and $0.20 \mathrm{~g}$ in the liquid fractions. The $4^{\text {th }}$ experiment provided the lowest lipids recoveries $(0.19 \mathrm{~g}$ of total lipids per $\mathrm{g}$ of dry matter and only $0.09 \mathrm{~g}$ in the liquid fractions) even with a long hydrolysis, and moderate temperature and enzyme concentration $\left(27 \mathrm{~h} 30,43^{\circ} \mathrm{C}, 2.3 \mathrm{~g} \cdot \mathrm{kg}^{-1}\right)$.

Concerning phospholipids, similar results were observed for total phospholipids extraction and their recovery into liquid fractions. The $11^{\text {th }}$ experiment appears to be the 
best one. Under such conditions, the total phospholipids has increased by $50 \%$ compared to chemical extraction and $33 \%$ of these phospholipids were recovered in the liquid fractions. At the opposite, conditions used in the first experiment conducted to the worst results (0.006 $\mathrm{g}$ of total phospholipids per $\mathrm{g}$ of dry heads and $0.003 \mathrm{~g}$ in the liquid fractions).

Predicted responses obtained

According to predicted responses, none of the conditions were found suitable for an optimisation of both $\mathrm{DH}$, lipids and phospholipids recoveries. Thus the optimisation procedures have been carried out considering only on lipid responses. Conditions resulting from the canonical analysis of the data were reported in Table 3 . The first part of this table indicates the conditions required to obtain the highest value for all responses studied and the regression factor ( $\mathrm{R}^{2}$ adjusted) of these predictions. The other part of Table 3 indicates the theoretical values for each studied response according to the conditions mentioned above. As example, to obtain the highest $\mathrm{DH}$, the hydrolysis should be conducted during $27 \mathrm{~h}(1605 \mathrm{~min})$, at $33^{\circ} \mathrm{C}$ and with an enzyme concentration of $2.0 \mathrm{~g} \cdot \mathrm{kg}^{-1}$. According to the prediction, the $\mathrm{DH}$ should be around $30 \%$, the total lipids quantity about $0.155 \mathrm{~g} . \mathrm{g}^{-1}$ of dry matter and the phospholipids about $0.004 \mathrm{~g} . \mathrm{g}^{-1}$ of dry matter. The software also indicated around $93.9 \%$ hardiness, which indicates the reliability. The regression given for the lipid response was a little lower $\left(R^{2}=75.2 \%\right)$ and very low for the phospholipids $\left(\mathrm{R}^{2}=48.7 \%\right)$ but it is important to notice that the conditions indicated for this response were closed to those needed for the lipid response. Canonical analysis revealed that the experimental conditions for the highest release of lipids and phospholipids were: hydrolysis time $=29 \mathrm{~min}$, temperature $=31^{\circ} \mathrm{C}$ and E/S ratio $=2.6 \mathrm{~g} \cdot \mathrm{kg}^{-1}$ at $\mathrm{pH} 8$ and with one volume of water added, following the pHstat method. The best explanatory model equation for the lipid release became:

Lipid releasing $=0,2260669+0,000186345$ time $+1,82655 \mathrm{E} / \mathrm{S}-0,0135053 \mathrm{~T}^{\circ}$ 0,00048255 time ${ }^{\star} E / S-0,00000333432$ time ${ }^{\star} T^{\circ}-0,0334821 E / S^{\star} T^{\circ}+0,000241924 T^{\circ 2}$

Three dimensional graphs, showing the influence of each variable on the lipid releasing are presented on Figure 1 (A: enzyme concentration and temperature; $\mathrm{B}$ : hydrolysis time and temperature; $\mathrm{C}$ : enzyme concentration and hydrolysis time). Profiles obtained here confirm values predicted in Table 3 , where lipids will be released in higher quantity with a short-time hydrolysis, a high enzyme concentration and at a moderate temperature. Thus, these graphs emphasize the strong influence of temperature and enzyme concentration. The accuracy of the model was further tested by conducting hydrolysis experiment.

Validation of the predicted value: hydrolysis conduced at optimised conditions for lipids release

$\mathrm{DH}$ and release of lipids and phospholipids

Results obtained after the conduction of the hydrolysis are reported in Table 4. Under such conditions, for a 29 min hydrolysis, the $\mathrm{DH}$ reached $3.5 \%$. Only $27 \%$ of the total matter was located into the liquid fractions after proteolysis. However, $80 \%$ of extracted lipids were located into liquid fractions and $60 \%$ in the oily one. Regarding phospholipids, they are mainly located in liquid fractions (56\%) as well, and especially into the soluble fraction.

Total fatty acid analysis 
Fatty acids of lipids recovered in each fraction were analysed by gas chromatography (Table 5). In all fractions, palmitic acid is the main fatty acid (more than 20\%). In the insoluble fraction, main fatty acid families were the $\omega 3(\sim 24 \%)$ and the $\omega 9(\sim 21 \%)$. Concerning the liquid fractions, the principal difference observed with the insoluble part was the PUFA proportion, more prominent in liquid fractions $(-28 \%)$ corresponding to a decrease of SFA ( $40 \%)$. Thus, the $\omega 3$ fatty acid family was the most important in the soluble fraction $(27.02 \pm 0.46 \%)$ followed by the oily fraction $(26.80 \pm 0.04 \%)$. The $\omega 9$ fatty acid family represented around $20 \%$ of total fatty acids in both liquid fractions.

Lipid class distribution

Results from TLC-FID analysis of sardine heads hydrolysis fractions were depicted in Figure 2. No free fatty acids, ketones, hydrocarbons or waxes were found on our samples and sterol esters were estimated as trace levels. The insoluble fraction was the most diversified. The tri-acylglycerols (TAGs) represented $36 \%$ of total lipids, followed by phospholipids (29\%). Other polar lipids (glycolipids (GLs), pigments, mono-acylglycerols (MAGs)) were found predominantly in the insoluble fraction (19\%). The sterol fraction was also mainly found in this fraction, representing $15 \%$ of total lipids. The oily fraction is almost exclusively composed of acylglycerols, especially TAG (68\% of total lipids). Less than $10 \%$ of the lipid composition of this fraction was represented by the phospholipids and the sterols. In the soluble fraction, $46 \%$ of the total lipids were TAG and $25 \%$ were represented by the GLs, MAGs, and pigments group. Phospholipids in this fraction represented around $20 \%$ of the total lipids.

Fatty acid analysis of lipid classes from liquid fractions

Fatty acid distribution of the neutral lipids and phospholipids resulted from the three fractions of the hydrolysis were then studied (Table 6, Table 7 and Table 8).

Insoluble fraction: neutral lipid fatty acids (Table 6) were mainly represented by SFAs (39\%) especially with palmitic acid (26\%). PUFAs were highly represented (36\%) and principally by the $\omega 3$ and $\omega 6$ families. Phospholipids possessed mainly SFAs (56\%). Phospholipid PUFAs were almost exclusively represented by EPA and DHA.

Oily fraction: neutral lipids were the only lipid class found significantly. Fatty acids (Table 7) were mainly represented by PUFAs (42\% of total fatty acids), essentially belonged to the $\omega 3$ family (75\% of PUFAs).

Soluble fraction: fatty acids of neutral lipids and phospholipids were reported in Table 8. Neutral lipids were essentially represented by PUFAs (41\%) with EPA and DHA as major components (around $23 \%$ of total fatty acids). SFAs represented $36 \%$ of total fatty acids, with $23 \%$ were palmitic acid. Phospholipids of the same fraction were depicted mainly by SFA (47\%), essentially with palmitic (31\%) and stearic (14\%) acids. Oleic acid is the major MUFA, where $\omega 9$ fatty acids family represented more than $25 \%$ of the total fatty acid. While PUFAs were the minor fatty acid class, they were constituted exclusively by EPA and DHA.

\section{Discussion}

Results obtained in the first part of the study have shown that hydrolysis could increase the extraction of lipids by $27 \%$ compared to classical extraction. Phospholipid quantity is also enhanced (up to 50\%), inducing the benefit of hydrolysis for phospholipid release. 
Natively, phospholipids are combined with proteins to form the membrane. Hydrolyses realized with proteases induce the membrane breakdown and consequently gave a more efficient phospholipid extraction, as shown before on other by-product matrixes. ${ }^{22}$ These results have also demonstrated that the lipids recovered into liquid fractions could reach $70 \%$ of the total quantity for lipids and 33\% for phospholipids, avoiding solvent utilisation. Thanks to results obtained, the enzyme concentration was the most influencial factor. Hydrolysis time is the second influent factor, but it leads to different effects according to the response. It is not beneficial to perform a long hydrolysis to obtain the highest lipid release. Indeed, the tissue disruption obtained at the beginning of the proteolysis appears sufficient to release the lipids. Moreover, the response surface profiles indicated that the lipid recovery on liquid fractions decreased with long hydrolysis. This phenomenon is due to the small peptides generation during long time hydrolysis, suggesting that these peptides produced had more accessible hydrophobic regions to interact with the lipids. Such complexes were then recovered in the sludge. Temperature variation does not affect the responses. While the contrary has been demonstrated in previous studies, ${ }^{25,26,36}$ it is surely due to the fact that our chosen temperature area is not wide enough and centered around the high enzyme activity temperature area (Protamex has an optimal temperature range from 31 to $55^{\circ} \mathrm{C}$ ). Other studies have also shown, with experimental design procedure, that temperature did not possess a significant effect on hydrolysis $(\mathrm{DH})$ when the temperature corresponded to the enzyme temperature range..$^{37,38}$

All these tendencies have been confirmed with the canonical analysis. Data treatment concerning the lipid responses indicates preferential operating conditions. The prediction was not as robust as the one obtained for $\mathrm{DH}$. Anyway, this analysis gave an indication of the conditions to use. Concerning phospholipid recovery, results obtained do not permit to obtain an accurate prediction, but the values of the parameters indicated for the phospholipids were the same as those predicted for the lipid response.

Thus, this statistical treatment demonstrated that lipid extraction was not linked to proteolysis (DH). Indeed, the hypothesis formulated at the beginning (the higher the $\mathrm{DH}$ is, the higher the breakdown of the matrix is, the smaller the peptides is and the higher the lipid release is) was contradicted by the present results because a low hydrolysis time was sufficient to obtain the highest lipid recovery. It was also demonstrated that DH and lipids were not only linked but were antinomic: experiments which have led to high $\mathrm{DH}$ values have led to low lipid recovery and vice versa. Recently, Šližyte et al. have shown that it was difficult to obtain, with the same conditions, the maximum lipid and protein recoveries. ${ }^{39}$ Nowadays, few works have been published focusing on lipid extraction by enzymatic way, most of the hydrolyses being devoted to protein fractions to produce hydrolysates with high nutritional value ${ }^{37,38,40,41}$ or to find any biological activity, such as antioxidant one ${ }^{42,43,44}$, anti-anaemia ${ }^{45}$ or secretagogue ${ }^{46}$ for example.

Hydrolysis conducted here has led to low solubility of the matter, which can be explained by the short hydrolysis. Quaglia and Orban, in 1987, have shown that hydrolysate solubility increases with $\mathrm{DH} .{ }^{47}$ However, hydrolyses have enabled to extract a high amount of lipids. After centrifugation, the main part was released in the liquid fractions, which was our principal objective. Additional mild steps (likewise ultrafiltration) could be used for purifying those liquid fractions. Phospholipids were extracted in higher quantity after hydrolysis. Despite the fact that a lot of phospholipids are still located in the insoluble fraction, an amount as high as the one obtained without hydrolysis is located in the liquid fractions, especially in the soluble fraction. Similar results were obtained after conducting a proteolysis (with Protamex and Flavourzyme) on marine by-products (salmon backbone and cod viscera) which is in accordance with our results. ${ }^{48,49}$ Thus, both liquid fractions present an interest in the lipid area. 
The fatty acid study showed that PUFAs were concentrated in liquid fractions. $\omega 3$ Fatty acids represented $27 \%$ of the total fatty acids in liquid fractions. Phospholipid results were located in soluble and insoluble fractions. Moreover, lipid class results obtained with both analytic methods gave the same results. Those analyses showed that insoluble fraction possess a higher lipid diversity (TAGs, sterols, MAGs, phospholipids) than the others.

Fatty acids contained in the neutral lipid of insoluble fraction were mainly SFAs and PUFAs. The recovery of those compounds could be studied in a further study, with additional hydrolysis, for example. Indeed, previous works realized in the Laboratory on other marine by-products have highlighted that a second hydrolysis has an interest. Hence, after conducting a hydrolysis on cod milt with Flavourzyme, the resulting sludge was more solubilized with a secondary hydrolysis with Protamex and more lipids were released. Other processes are using several hydrolyses, in order to increase functional properties of hydrolysate or to reduce their bitterness for example. ${ }^{50,51}$ This process could also be used, for the insoluble fraction, to release lipids, proteins, carbohydrates... Liquid fractions were less diversified because the oily fraction was only composed of neutral lipids and the soluble fraction is composed of MAGs, TAGs and phospholipids. Fatty acid composition of oily fraction neutral lipids was mainly PUFAs and especially $\omega 3$ fatty acids. Similar fatty acid composition was obtained concerning neutral lipid soluble fraction. Phospholipid fatty acids of soluble fraction were mainly SFA. However, PUFA were only EPA and DHA.

Sardine heads hydrolysis has shown a large interest for lipid recovery. Extracted lipid quantities were not more significant than those obtained with classical chemical extraction, but the hydrolysis conducted with Protamex permitted to release the lipids in the liquid fractions. Soluble and oily fractions had moreover a qualitative interest. Indeed, oily fraction is mainly composed of $\omega 3$ fatty acid rich neutral lipids and soluble fraction possesses three main cards: $\omega 3$ fatty acid rich neutral lipids, a high phospholipid quantity, and its protein content. While oily fraction can be recovered including a centrifugation step and then a micro-filtration, the soluble fraction should be finely purified using ultrafiltration techniques, in order to separate lipid and peptides parts. ${ }^{52}$

\section{Acknowledgements}

This work was performed within the Integrated Research Project SEAFOODplus, contract No FOOD-CT-2004-506359 and within the PCRDT $6^{\text {th }}$. The partial financing of the work by the European Union is gratefully acknowledged. Authors also wish to thank the Euro Seafood Trading Company (France) for providing a PhD grant for this research. This work has been performed using the SiobioCle LIMS (Chatou, France).

\section{References}

1 FAO Fisheries department, The state of world fisheries and aquaculture. SOFIA 198p (2006).

2 OFIMER, Les chiffres clés de la filière pêche et aquaculture en France. Office national interprofessionnel des produits de la mer et de l'aquaculture 30p (2006). 
3 Dumay J., Extraction of lipids by enzymatic bioreactor combined to ultrafiltration: application to the upgrading of fish (Sardina pilchardus) by-products. PhD thesis, Nantes University 306p (2006).

$4 \quad$ Piclet G., Le poisson aliment. Composition - intérêt nutritionnel. Cahiers de la nutrition et de la diététique 4 : 317-36 (1987).

5 Médale F., Lefèvre, F. and Corraze, G., Qualité nutritionnelle des poissons. Constituants de la chair et facteurs de variations. Cahiers de la nutrition et de la diététique 38 : 37-44 (2003).

6 Murakami M., Makabe, K., Okada, S., Yamaguchi, K. and Konosu, S., Screening of biologically active compounds in microalgae. Nippon Suisan Gakkaishi 54 : 1035-9 (1988).

7 Cheng L., Hostetler, K.Y., Chaidhawangul, S., Gardner, M.F., Beadle, J.R., Keefe, K.S., Bergeron-Lynn, G., Severson, G.M., Soules, K.A., Mueller, A.J. and Freeman, W.R., Intravitreal toxicology and duration of efficacy of a novel antiviral lipid prodrug of ganciclovir in liposome formulation. Invest. Ophtalmol. Vis. Sc. 41 : 1523-31 (2000).

8 Hostetler K.Y., Korba, B.E., Sridhar, C.N. and Gardner, M.F., Antiviral activity of phosphatidyl-dideoxycytidine in hepatitis B-infected cells and enhanced hepatic uptake in mice. Antiviral Res. 24 : 59-67 (1994).

9 Barnerjee I., Saha, S. and Dutta, J., Comparison of the effect of dietary fish oils with different $n-3$ polyunsaturated fatty acid compositions on plasma and liver lipids in rats. Lipids $27:$ 425-8 (1992).

10 Mortensen S.H., Børshein, K.Y., Rainuzzo, J.R. and Knutsen, G., Fatty acid and elemental composition of the marine diatom Chaetoceros gracilis Schütt. Effects of silicate deprivation, temperature and light intensity. J. Exp. Mar. Biol. Ecol. 122 : 173-85 (1988).

11 Mahadik S.P., Evans, D. and Lal H., Oxidative stress and role of antioxidant and omega-3 essential fatty acids supplementation on schizophrenia. Prog. Neuropsychopharmacol. Biol. Pshychiatry 23 : 463-93 (2001).

12 Bourre J.M., Dietary omega-3 Fatty acids and psychiatry: mood, behaviour, stress, depression, dementia and aging. J. Nutr. Health Aging 9 : 31-8 (2005).

13 Weisinger H.S., Armitage, J.A., Sinclair, A.J., Vingrys, A.J., Burns, P.L. and Weisinger, R.S., Perinatal omega-3 fatty acid deficiency affetcs blood pressure later in life. Nature Medecine $7: 258-9$ (2001).

14 Brouwer I.A., Geelen, A. and Katan, M.B., n-3 Fatty acids, cardiac arrhythmia and fatal coronary heart disease. Prog. Lipid. Res. 45 : 357-67 (2006).

15 Reiffel J. and McDonald, A., Antiarrhythmic effects of omega-3 fatty acids. Am. J. Cardiol. 98 : 50-60 (2006).

16 Kris-Etherton P. , Psota, T.L. and Gebauer, S.K., Dietary omega-3 fatty acid intake and cardiovascular risk. Am. J. Cardiol. 98 : 3-18 (2006).

17 Jacobson T.A., Secondary prevention of coronary heart disease with omega-3 fatty acids. Am. J. Cardiol. 98 : 61-70 (2006).

18 Bergé J.P. and Barnathan, G., Fatty acids from lipids in marine organisms: molecular biodiversity, roles as biomarkers, biologically active compounds, and economical aspects. Adv. Biochem. Biotechnol. 96 : 49-125 (2005).

19 Falch E., Rustad, T. and Aursand, M., By-products from gadiform species as raw materal for production of marine lipids as ingredients in food or feed. Process Biochem. 41 : 666-74 (2006).

20 Njnkoué J.M., Barnathan, G., Miralles, J., Gaydou, E.M. and Samb, A., Lipids and fatty acids in muscle, liver ans skin of three edible fish from the Senegalese 
coast: Sardinella maderensis, Sardinella aurita and Cephalopholis taeniops. Comp. Biochem. Physiol. B 131 : 394-402 (2002).

21 Kebir M.V.O.E., Barnathan, G., Gaydou, E.M., Siau, Y. and Miralles, J., Fatty acids in Liver, Muscle and Gonad of three Tropical Rays including Non-MethyleneInterrupted Dienoic Fatty Acids. Lipids 42 : 525-35 (2007).

22 Dumay J., Barthomeuf, C. and Bergé, J.P., How enzymes may be helpful for upgrading fish by-products: enhancement of fat extraction. J. Aquatic Fish Product Technol. 13 : 69-84 (2004).

23 Šliźyte R., Daukšas, E., Falch, E., Storrø, I. and Rustad, T., Yield and composition of different fractions obtained after enzymatic hydrolysis of cod (Gadus morhua) by-products. Process Biochem. 1415-24 (2005).

24 Dumay J., Donnay-Moreno, C., Barnathan, G., Jaouen, P. and Bergé, J.P., Improvement of lipid and phospholipid recoveries from sardine (Sardina pilchardus) viscera using industrial protases. Process Biochem. 41 : 2327-32 (2006).

25 Diniz F.M. and Martin, A.M., Use of response surface methodology to describe the combined effects of $\mathrm{pH}$, temperature and $\mathrm{E} / \mathrm{S}$ ratio on the hydrolysis of dogfish (Squalus acanthias) muscle. Int. J. Food Sci. Technol. 31 : 419-26 (1996).

26 Guérard F., Sumaya-Martinez, M.T., Laroque, D., Chabeaud, A. and Dufossé, L., Optimization of free radical scavenging activity by response surface methodology in the hydrolysis of shrimp processing discards. Process Biochem. 42 : 1486-91 (2007).

27 Silva A., Morphometric variation among sardine (Sardina pilchardus) populations from the northeastern and the western Mediterranean. ICES J. Marine Sci. 60 : 1352-60 (2003).

28 Caponio F., Lestingi, A., Bilanca, M.T. and Laudadio, V., Chemical characteristics and lipid fraction quality of sardines (Sardina pilchardus W.): influence of sex and length. J. Appl. Ichtyol. $20: 530-5$ (2004).

29 Liaset B., Nortvedt, R., Lied, E. and Espe, M., Studies on the nitrogen recovery in enzymic hydrolysis of atlantic salmon (Salmo salar, L.) frames by protamex protease. Process Biochem 37 : 1263-9 (2002).

30 Adler-Nissen J., Enzymic hydrolysis of food proteins. New York: Elsevier, Applied Science Publishers 110-69 (1986).

31 Crooke W.M. and Simpson, W.E., Determination of ammonium in Kjeldhal digests of crops by an automated procedure. J. Agric. Food Chem. 27 : 1256-62 (1971).

32 Folch J., Lees, M. and Sloan Stanley, G.H., A simple method for the isolation and purification of total lipids from animal tissues. J. Biol. Chem. 226 : 497-509 (1957).

33 Stewart J.C.M., Colorimetric determination of phospholipids with ammonium ferrothiocyanate. Anal. Biochem. 104 : 10-4 (1980).

$34 \quad$ Parrish C.C., Separation of aquatic lipids classes by chromarod thin-layer chromatography with measurement by latroscan flame ionisation detection. Can. J. Fish. Aquat. Sci. 4 : 722-31 (1987).

35 Ackman R.G., McLeod, C.A. and Banerjee, A.K., An overview of analyses by chromarod-latroscan TCL-FID. J. of Planar Chromatography 3 : 350-490 (1990).

36 Ravallec-Plé R., Valorisation d'hydrolysats d'origine marine: optimisation de la concentration en peptides apparentés aux facteurs de croissance et aux agents sécrétagogues. Thčse de doctorat de l'Université de Bretagne Occidentale 171p (2000).

37 Nilsang S., Lertsiri, S., Suphantharika, M. and Assavanig, A., Optimization of enzymatic hydrolysis of fish soluble concentrate by commercial proteases. J. Food Eng. 70 : $571-8$ (2005). 
38 Sumaya-Martínez T., Castillo-Morales, A., Favela-Torres, E.H.-O.S. and Prado-Barragán, L.A., Fish protein hydrolysates from gold carp (Carassius auratus): I. A study of hysolysis parameters using response surface methodology. J. Sci. Food Agric. 85 : 98-104 (2005).

39 Šližyte R. , Rustad, T. and Storrř, I., Enzymatic hydrolysis of cod (Gadus morhua) by-products. Optimization of yield and properties of lipid and protein fractions. Process Biochem. 40 : 3680-92 (2005).

40 Liaset B. and Espe, M., Nutritional composition of soluble and insoluble fractions obtained by enzymatic hydrolysis of fish raw-materials. Process Biochem. 43 : 42-8 (2008).

41 Bhaskar N., Benila, T., Radha, C. and Lalitha, R.G., Optimization of enzymatic hydrolysis of visceral waste proteins of Catla (Catla catla) for preparing hydrolysate using a commercial protease. Bioresource Technol. 99 : 335-43 (2008).

42 Dong S., Zeng, M., Wang, D., Liu, Z., zhao, Y. and Yang, H., Antioxydant and biochemical properties of protein hydrolysates prepared from Silver carp (Hypophtalmichtys molitrix). Food Chem. 107 : 1485-93 (2008).

43 Klompong V., Benjakul, S., Kantachote, D. and Shahidi, F., Antioxydative activity and functional properties of protein hydrolysate of yellow stripe trevally (Selaroides leptolepis) as influenced by the degree of hydrolysis and enzyme type. Food Chem. 102 : 1317-27 (2007).

44 Thiansilakul Y., Benjakul, S. and Shahidi, F., Compositions, functional properties and antioxidative activity of protein hydrolysates prepared from round scad (Decapterus maruadsi). Food Chem. 103 : 1385-94 (2007).

45 Dong Y.L., Sheng, G.Y., Fu, J.M. and Wen, K.W., Chemical characterization and anti-anaemia activity of fish protein hydrolysate from Saurida elongata. J. Sci. Food Agric. 85 : 2033-39 (2005).

46 Ravallec-Plé R., Charlot, C., Pires, C., Braga, V., Batista, I., Van Wormhoudt, A., Le Gal, Y. and Fouchereau-Péron, M., The presence of bioactive peptides in hydrolysates prepared from processing waste of sardine (Sardina pilchardus). J. Sci. Food Agric. 81 : 1120-5 (2001).

47 Quaglia G.B. and Orban, E., Influence of enzymatic hydrolysis on structure and emulsifying properties of sardine (Sardina pilchardus) protein hydrolysate. J. Food Sci. 55 : 1571-3 (1990).

48 Liaset B., Julsham, K. and Espe, M., Chemical composition and theoretical nutritional evaluation of the produced fractions from enzymic hydrolysis of salmon frames with Protamex. Process Biochem. 38 : 1747-59 (2003).

49 Daukšas E., Falch, E., Šližyte, R. and Rustad, T., Composition of fatty acids and lipid classes in bulk products generated during enzymic hydrolysis of cod (Gadus morhua) by-products. Process Biochem. 40 : 2659-70 (2005).

50 You-Jin J., Hee-Guk, B. and Se-Kwon, K., Improvement of functional properties of cod frame protein hydrolystaes using ultrafiltration membranes. Process Biochem. 35 : 471-8 (1999).

51 Liaset B., Lied, E. and Espe, M., Enzymatic hydrolysis of by-products from the fish-filleting industry; chemical characterization and nutritional evaluation. J. Sci. Food Agric. 80 : 881-9 (2000).

52 Dumay J., Radier, S., Barnathan, G., Bergé, J.P. and Jaouen, P., Recovery of valuable soluble compounds from washing waters generated during small fatty pelagic surimi processing by membrane processes. Journal of Environmental Technology 29 : 451-61 (2007). 


\section{Tables}

Table 1

Experimental design levels of the independent variables used in the hydrolysis of sardine heads with Protamex

\begin{tabular}{cccc}
\hline $\begin{array}{c}\text { Levels of independant } \\
\text { variables used }\end{array}$ & $\begin{array}{c}\text { Hydrolysis time } \\
(\mathrm{min})\end{array}$ & $\begin{array}{c}\text { Temperature } \\
\left({ }^{\circ} \mathrm{C}\right)\end{array}$ & $\begin{array}{c}\text { E/S ratio } \\
\left(\mathrm{g} . \mathrm{kg}^{-1}\right)\end{array}$ \\
\hline-1.68 & 29 & 31 & 0.2 \\
-1 & 358 & 36 & 0.7 \\
0 & 840 & 43 & 1.5 \\
+1 & 1322 & 50 & 2.3 \\
+1.68 & 1651 & 55 & 2.8 \\
\hline
\end{tabular}


Table 2

Proteolysis conditions and responses for Degree of Hydrolysis, Lipid and Phospholipids (sum of all fractions and sum of oily and aqueous fractions i.e. liquid fractions) obtained for the Central Composite Design

\begin{tabular}{|c|c|c|c|c|c|c|c|c|}
\hline \multirow{3}{*}{ Experiment number } & \multicolumn{3}{|c|}{$\begin{array}{r}\text { Proteolysis conditions } \\
\end{array}$} & \multicolumn{5}{|c|}{ Responses obtained } \\
\hline & \multirow{2}{*}{$\frac{\text { Hydrolysis time }}{\text { (min) }}$} & \multirow{2}{*}{$\frac{\text { Temperature }}{\left({ }^{\circ} \mathrm{C}\right)}$} & \multirow{2}{*}{$\begin{array}{l}\text { E/S ratio } \\
\text { (g.kg-1) }\end{array}$} & \multirow{2}{*}{ DH } & \multicolumn{2}{|c|}{ Lipids (g/g of dry heads) } & \multicolumn{2}{|c|}{ Phospholipids (g/g of dry heads) } \\
\hline & & & & & All fractions & liquid fractions & All fractions & liquid fractions \\
\hline 1 & 1322 & 36 & 2.3 & $28 \%$ & 0.22 & 0.14 & 0.006 & 0.003 \\
\hline 2 & 840 & 43 & 2.8 & $24 \%$ & 0.19 & 0.11 & 0.010 & 0.004 \\
\hline 3 & 840 & 43 & 1.5 & $24 \%$ & 0.21 & 0.13 & 0.012 & 0.006 \\
\hline 4 & 1651 & 43 & 1.5 & $23 \%$ & 0.19 & 0.09 & 0.010 & 0.002 \\
\hline 5 & 29 & 43 & 1.5 & $8 \%$ & 0.22 & 0.13 & 0.018 & 0.004 \\
\hline 6 & 840 & 43 & 1.5 .2 & $13 \%$ & 0.20 & 0.13 & 0.019 & 0.004 \\
\hline 7 & 358 & 50 & 1.5 .7 & $9 \%$ & 0.23 & 0.17 & 0.016 & 0.005 \\
\hline 8 & 840 & 43 & 1.5 & $22 \%$ & 0.21 & 0.13 & 0.012 & 0.004 \\
\hline 9 & 358 & 36 & 2.3 & $9 \%$ & 0.29 & 0.20 & 0.015 & 0.007 \\
\hline 10 & 840 & 31 & 1.5 & $21 \%$ & 0.22 & 0.15 & 0.016 & 0.009 \\
\hline 11 & 358 & 36 & 1.5 .7 & $7 \%$ & 0.22 & 0.11 & 0.021 & 0.007 \\
\hline 12 & 840 & 55 & 1.5 & $11 \%$ & 0.23 & 0.15 & 0.020 & 0.006 \\
\hline 13 & 1322 & 36 & 1.5 .7 & $23 \%$ & 0.23 & 0.15 & 0.010 & 0.003 \\
\hline 14 & 1322 & 50 & 2.3 & $17 \%$ & 0.21 & 0.08 & 0.012 & 0.004 \\
\hline 15 & 358 & 50 & 2.3 & $12 \%$ & 0.22 & 0.16 & 0.020 & 0.008 \\
\hline 16 & 1322 & 50 & 1.5 .7 & $12 \%$ & 0.22 & 0.14 & 0.018 & 0.005 \\
\hline
\end{tabular}


Table 3

Optimal conditions calculated for each response and values predicted statistically according to those optimal conditions

\begin{tabular}{|c|c|c|c|c|}
\hline & Response & DH & Lipid released & PL released \\
\hline \multirow{3}{*}{ 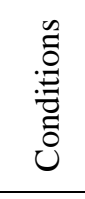 } & Time (min) & 1605 & 29 & 29 \\
\hline & Enzyme (g. $\mathrm{kg}^{-1}$ of raw material) & 2.0 & 2.6 & 2.8 \\
\hline & Temperature $\left({ }^{\circ} \mathrm{C}\right)$ & 33 & 31 & 32 \\
\hline & $\mathrm{R}^{2}$ adjusted & 93.9 & 75.2 & 48.7 \\
\hline \multirow{3}{*}{ 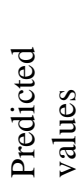 } & DH (\%) & 30 & Out of range & Out of range \\
\hline & Lipids released (g.g ${ }^{-1}$ of dry heads) & 0.155 & 0.239 & 0.255 \\
\hline & PL ${ }^{*}$ released (g.g ${ }^{-1}$ of dry heads) & 0.004 & 0.009 & 0.009 \\
\hline
\end{tabular}

${ }^{*}$ PL: Phospholipids 


\section{Table 4}

Degree of hydrolysis, dry matter distribution, lipids and phospholipid recoveries obtained after processing the optimal hydrolysis

\begin{tabular}{lccc|c} 
& Aqueous & Oily & Insoluble & Total \\
\hline $\mathrm{DH}$ & - & - & - & $3.5 \%$ \\
Dry matter distribution & $27 \%$ & $20 \%$ & $53 \%$ & $100 \%$ \\
$\begin{array}{l}\text { Lipids (g.g } \mathrm{g}^{-1} \text { of dry } \\
\begin{array}{l}\text { heads) } \\
\text { Phospholipids (g.g } \mathrm{g}^{-1} \text { dry heads) }\end{array}\end{array}$ & 0.03 & 0.11 & 0.04 & 0.18 \\
\hline
\end{tabular}


Table 5

Fatty acid distribution (\%) among fractions obtained after optimized hydrolysis. SFA: saturated fatty acids, MUFA: mono-unsaturated fatty acids, PUFA: poly-unsaturated fatty acids

\begin{tabular}{|c|c|c|c|}
\hline & Insoluble & Oily & Aqueous \\
\hline C14:0 & $8.5 \pm 0.1$ & $11.7 \pm 0.3$ & $8.5 \pm 0.2$ \\
\hline C16:0 & $28.2 \pm 0.5$ & $23.7 \pm 0.1$ & $25.5 \pm 0.3$ \\
\hline C18:0 & $6.2 \pm 0.1$ & $4.0 \pm 0.0$ & $5.6 \pm 0.0$ \\
\hline C20:0 & $0.6 \pm 0.0$ & $0.4 \pm 0.3$ & $0.6 \pm 0.0$ \\
\hline$\Sigma$ SFA & $43.5 \pm 0.7$ & $39.8 \pm 0.1$ & $40.2 \pm 0.5$ \\
\hline C16:1 c $\omega 7$ & $6.1 \pm 0.1$ & $7.4 \pm 0.0$ & $6.4 \pm 0.1$ \\
\hline C18:1 c $\omega 9$ & $10.4 \pm 0.1$ & $8.0 \pm 0.0$ & $10.1 \pm 0.1$ \\
\hline C18:1 c $\omega 7$ & $3.0 \pm 0.0$ & $2.6 \pm 0.0$ & $2.7 \pm 0.0$ \\
\hline C20:1 c $\omega 9$ & $4.6 \pm 0.0$ & $5.5 \pm 0.0$ & $4.6 \pm 0.0$ \\
\hline C22:1 c $\omega 9$ & $4.4 \pm 0.1$ & $5.7 \pm 0.0$ & $4.5 \pm 0.0$ \\
\hline C24:1 c $\omega 9$ & $1.6 \pm 0.1$ & $0.7 \pm 0.0$ & $1.4 \pm 0.1$ \\
\hline$\Sigma$ MUFA & $29.8 \pm 0.1$ & $29.9 \pm 0.0$ & $30.0 \pm 0.3$ \\
\hline C16:2 c $\omega 4$ & $0.6 \pm 0.0$ & $0.9 \pm 0.0$ & $0.7 \pm 0.0$ \\
\hline C18:2 c $\omega 6$ & $1.5 \pm 0.0$ & $1.6 \pm 0.0$ & $1.5 \pm 0.0$ \\
\hline C18:3 c $\omega 3$ & $0.9 \pm 0.0$ & $1.3 \pm 0.0$ & $1.0 \pm 0.0$ \\
\hline C20:3 c $\omega 3$ & $0.8 \pm 0.0$ & $0.5 \pm 0.0$ & $0.8 \pm 0.0$ \\
\hline C18:4 c $\omega 3$ & $2.7 \pm 0.1$ & $4.4 \pm 0.0$ & $3.4 \pm 0.0$ \\
\hline C20:4 c $\omega 5$ & $0.7 \pm 0.0$ & $0.9 \pm 0.0$ & $0.8 \pm 0.0$ \\
\hline C20:5 c $\omega 3$ & $6.7 \pm 0.2$ & $9.3 \pm 0.0$ & $8.3 \pm 0.1$ \\
\hline $\mathrm{C} 22: 5 \mathrm{c} \omega 3$ & $0.8 \pm 0.0$ & $1.0 \pm 0.0$ & $0.9 \pm 0.0$ \\
\hline $\mathrm{C} 22: 6 \mathrm{c} \omega 3$ & $12.0 \pm 0.5$ & $10.3 \pm 0.0$ & $12.6 \pm 0.4$ \\
\hline$\Sigma$ PUFA & $24.5 \pm 0.9$ & $27.7 \pm 0.1$ & $27.9 \pm 0.5$ \\
\hline
\end{tabular}


Table 6

Neutral lipid and phospholipid fatty acid composition (\%) in the insoluble fraction generated during the optimized hydrolysis of sardine heads by Protamex. SFA: saturated fatty acids, MUFA: mono-unsaturated fatty acids, PUFA: poly-unsaturated fatty acids

\begin{tabular}{|c|c|c|}
\hline & \multirow[b]{2}{*}{ Neutral lipids } & \\
\hline & & Phospholipids \\
\hline C14:0 & $7.3 \pm 0.2$ & $2.0 \pm 0.2$ \\
\hline C16:0 & $25.8 \pm 1.0$ & $42.0 \pm 1.2$ \\
\hline C18:0 & $5.9 \pm 0.1$ & $12.2 \pm 0.3$ \\
\hline$\Sigma$ SFA & $39.0 \pm 1.0$ & $56.2 \pm 1.2$ \\
\hline C16:1 c $\omega 7$ & $7.5 \pm 0.1$ & $3.8 \pm 0.2$ \\
\hline C18:1 c $\omega 9$ & $12.5 \pm 0.2$ & $20.8 \pm 0.2$ \\
\hline C18:1 c $\omega 7$ & $3.8 \pm 0.1$ & $4.6 \pm 0.0$ \\
\hline C22:1 c $\omega 9$ & $1.0 \pm 0.0$ & $-\quad-$ \\
\hline$\Sigma$ MUFA & $24.8 \pm 0.4$ & $29.1 \pm 0.3$ \\
\hline C18:2 c $\omega 6$ & $1.4 \pm 0.0$ & $-\quad-$ \\
\hline C22:2 c $\omega 6$ & $6.3 \pm 0.1$ & - \\
\hline C20:3 c $\omega 6$ & $1.0 \pm 0.0$ & - \\
\hline C18:4 c $\omega 3$ & $2.2 \pm 0.1$ & - \\
\hline C20:4 c $\omega 3$ & $5.3 \pm 0.1$ & - \\
\hline C20:5 c $\omega 3$ & $7.2 \pm 0.4$ & $4.0 \pm 0.3$ \\
\hline C22:5 c $\omega 3$ & $0.9 \pm 0.1$ & $-\quad-$ \\
\hline C22:6 c $\omega 3$ & $12.1 \pm 0.6$ & $10.7 \pm 1.2$ \\
\hline$\Sigma$ PUFA & $36.3 \pm 1.1$ & $14.7 \pm 1.5$ \\
\hline
\end{tabular}


Table 7

Neutral lipid fatty acid composition (\%) in the oily fraction generated during the optimized hydrolysis of sardine heads by Protamex

\begin{tabular}{lrl} 
& Mean & $\begin{array}{l}\text { Standard } \\
\text { deviation }\end{array}$ \\
\hline C14:0 & $8.3 \pm$ & \pm .2 \\
C16:0 & $21.7 \pm$ & \pm .3 \\
C18:0 & $4.5 \pm \pm 0.1$ \\
$\Sigma$ SFA & $34.4 \pm 0.3$ \\
C16:1 c $\omega 7$ & $8.6 \pm 0.1$ \\
C18:1 c $\omega 9$ & $11.0 \pm 0.1$ \\
C18:1 c $\omega 7$ & $3.6 \pm 0.0$ \\
C22:1 c $\omega 9$ & $0.9 \pm 0.0$ \\
$\Sigma$ MUFA & $\mathbf{2 4 . 0} \pm \mathbf{0 . 2}$ \\
C18:2 c $\omega 6$ & $1.5 \pm 0.0$ \\
C22:2 c $\omega 6$ & $7.8 \pm 0.1$ \\
C20:3 c $\omega 6$ & $1.8 \pm 0.0$ \\
C18:4 c $\omega 3$ & $3.0 \pm 0.0$ \\
C20:4 c $\omega 3$ & $6.0 \pm 0.1$ \\
C20:5 c $\omega 3$ & $9.9 \pm 0.2$ \\
C22:5 c $\omega 3$ & $1.1 \pm 0.0$ \\
C22:6 c $\omega 3$ & $11.2 \pm 0.3$ \\
$\Sigma$ PUFA & $\mathbf{4 1 . 7} \pm \mathbf{0 . 4}$ \\
\hline
\end{tabular}


Table 8

Neutral lipid and phospholipid fatty acid composition (\%) in the soluble fraction generated during the optimized hydrolysis of sardine heads by Protamex

\begin{tabular}{|c|c|c|}
\hline & Neutral lipids & Phospholipids \\
\hline C14:0 & $7.6 \pm 0.4$ & $1.6 \pm 0.2$ \\
\hline C16:0 & $23.3 \pm 1.1$ & $31.1 \pm 0.8$ \\
\hline C18:0 & $5.1 \pm 0.0$ & $14.1 \pm 0.3$ \\
\hline$\Sigma$ SFA & $35.9 \pm 1.4$ & $46.8 \pm 0.9$ \\
\hline C16:1 c $\omega 7$ & $8.0 \pm 0.3$ & $3.3 \pm 0.2$ \\
\hline C18:1 c $\omega 9$ & $11.8 \pm 0.2$ & $23.1 \pm 0.5$ \\
\hline C18:1 c $\omega 7$ & $3.6 \pm 0.1$ & $3.8 \pm 0.1$ \\
\hline C24:1 c $\omega 9$ & $-\quad-$ & $2.7 \pm 0.1$ \\
\hline$\Sigma$ MUFA & $23.4 \pm 0.5$ & $32.9 \pm 0.3$ \\
\hline C18:2 c $\omega 6$ & $1.5 \pm 0.0$ & - \\
\hline C22:2 c $\omega 6$ & $6.2 \pm 0.5$ & - \\
\hline C20:3 c $\omega 6$ & $0.8 \pm 0.7$ & - \\
\hline C18:4 c $\omega 3$ & $2.9 \pm 0.1$ & - \\
\hline C20:4 c $\omega 3$ & $5.6 \pm 0.2$ & - \\
\hline C20:5 c $\omega 3$ & $9.7 \pm 0.2$ & $5.0 \pm 0.1$ \\
\hline C22:5 c $\omega 3$ & $0.7 \pm 0.6$ & - \\
\hline $\mathrm{C} 22: 6$ c $\omega 3$ & $13.4 \pm 0.5$ & $15.3 \pm 0.4$ \\
\hline$\Sigma$ PUFA & $40.8 \pm 1.7$ & $20.3 \pm 0.5$ \\
\hline
\end{tabular}




\section{Figures}
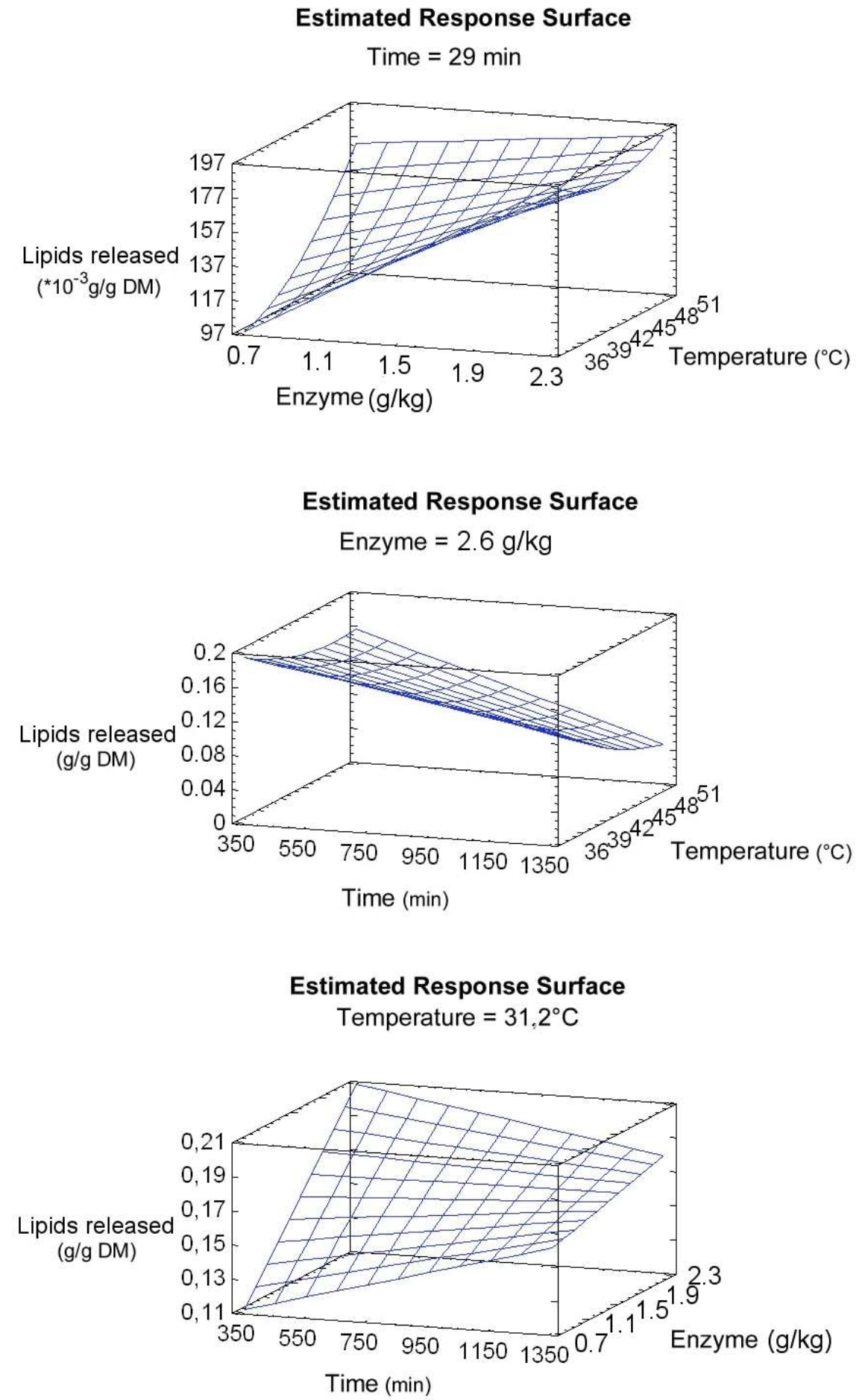

Figure 1

Estimated Response Surfaces according to the time, enzyme and temperature parameters 


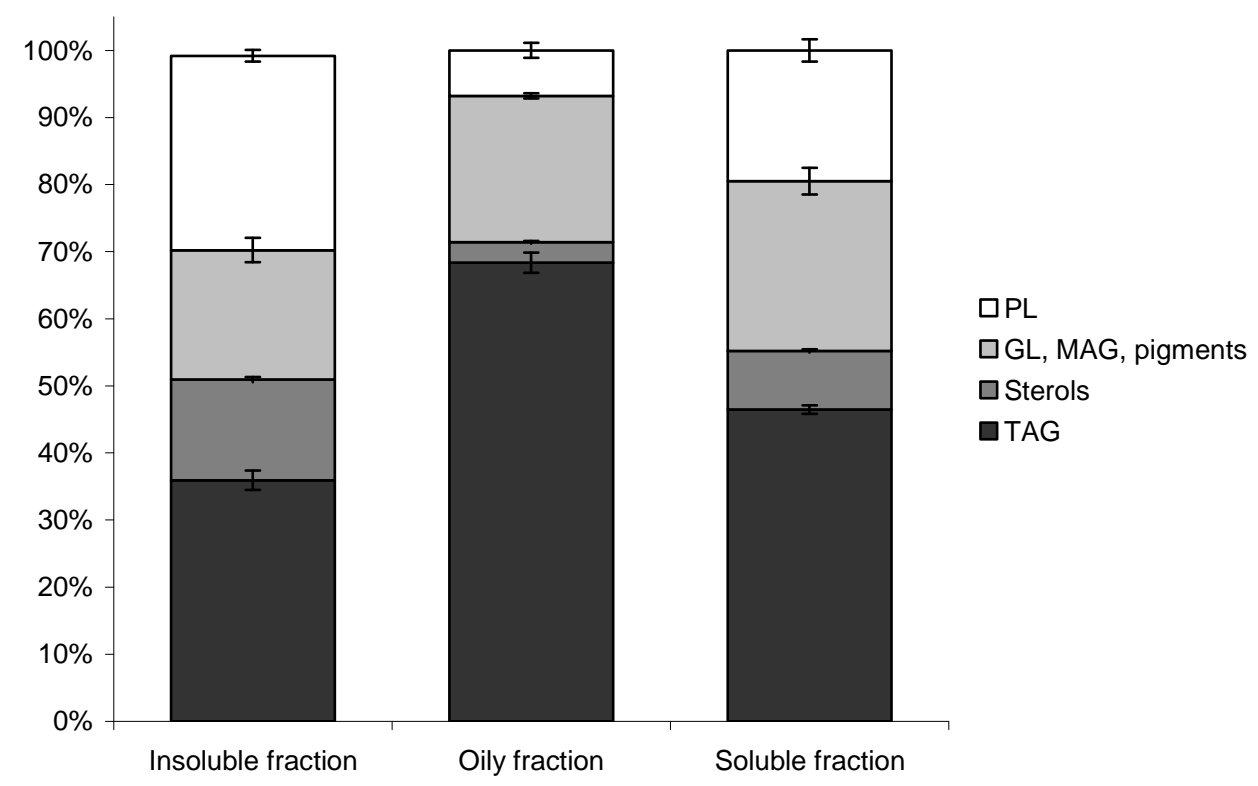

Figure 2

Lipid class distribution obtained by TLC-FID of fractions resulted from hydrolyzed sardine heads. PL: phospholipids, GL: glycolipids, MAG: monoacylglycerols, TAG: triacylglycerols 